\title{
Analisis Pengaruh Rasio Profitabilitas dan Economic Value Added terhadap Harga Saham pada Sub Sektor Industri Semen yang Terdaftar di Bursa Efek Indonesia
}

\author{
Anggita Mugi \\ Departemen Manajemen, Fakultas Ekonomi dan Manajemen \\ Institut Pertanian Bogor \\ Kampus Darmaga Bogor 16680 \\ Abdul Kohar Irwanto \\ Departemen Manajemen, Fakultas Ekonomi dan Manajemen \\ Institut Pertanian Bogor \\ Kampus Darmaga Bogor 16680 \\ Yusrina Permanasari \\ Departemen Manajemen, Fakultas Ekonomi dan Manajemen \\ Institut Pertanian Bogor \\ Kampus Darmaga Bogor 16680 \\ e-mail: yusrina.p@gmail.com
}

\begin{abstract}
The purpose of this research is to identify the effects of Return On Asset (ROA), Return On Equity (ROE), Net Profit Margin (NPM), Earning Per Share (EPS) and Economic Value Added (EVA) on the stock price. Sample used are the companies from the cement subsector registered in BEI from 2009 to 2011. Independent variables used are ROA, ROE, NPM, EPS and EVA, while the dependent variable is the stock price. The data in this research were analyzed by using the panel data regression including the cross section data and time series data. The results of panel data regression show that variables of ROA, ROE, NPM, EPS and EVA simultaneously have significant effects on the stock price because $p$-value $(0,000)<$ alpha (0.05). At the same time partially, the variables of EVA do not have a significant effect on the stock price because its $p$-value is (0.0683) > alpha (0.05), and variables of ROA, ROE, NPM and EPS partially affect the stock price with P-value $0.0002 ; 0.0013 ; 0.0008 ; 0.000$ respectively. The result of the determination coefficient analysis is $95.51 \%$, showing that the independent variables that exist in this regression is able to explain until $95.51 \%$ while the rest $4.49 \%$ is likely to be explained by other factors which are not described in this model.
\end{abstract}

Keywords : ROA, ROE, NPM, EPS, EVA, Stock Price

\section{ABSTRAK}

Penelitian ini bertujuan untuk mengetahui pengaruh Return On Asset (ROA), Return On Equity (ROE), Net Profit Margin (NPM), Earning Per Share (EPS) dan Economic Value Added (EVA) terhadap harga saham. Sampel yang digunakan adalah perusahaan sub sektor industri semen yang terdaftar di BEI periode 2009-2011. Variabel independen yang digunakan adalah ROA, ROE, NPM, EPS dan EVA dengan variabel dependennya adalah harga saham. Metode analisis yang digunakan adalah regresi data panel yang meliputi data cross section dan time series. Hasil analisis regresi data panel menunjukkan bahwa secara simultan variabel ROA, ROE, NPM, EPS dan EVA berpengaruh secara signifikan terhadapa harga saham karena nilai $p$-value $(0.000)<$ alpha (0.05). Sedangkan secara parsial variabel EVA tidak berpengaruh secara signifikan terhadap harga saham karena nilai p-value pada EVA (0.0683) > alpha 
140| Mugi, Irwanto, Permanasari - Analisis Pengaruh Rasio Profitabilitas

$(0,05)$ dan variabel ROA, ROE, NPM dan EPS berpengaruh secara parsial terhadap harga saham dengan nilai p-value berturut-turut sebesar $(0.0002 ; 0.0013 ; 0.0008 ; 0.000)$. Hasil uji analisis koefisien determinasi adalah sebesar $95.51 \%$ hal ini bahwa variabel independen yang ada pada regresi ini mampu menjelaskan sebesar $95.51 \%$ dan sisanya $4.49 \%$ kemungkinan dijelaskan oleh faktor lain yang tidak dijelaskan ke dalam model ini.

Kata Kunci : ROA, ROE, NPM, EPS, EVA, Harga Saham

\section{Pendahuluan}

Perusahaan pada umumnya bertujuan memaksimalkan kekayaan pemegang saham dengan cara memaksimalkan nilai saham perusahaan (Keown 2004). Untuk mencapainya maka perusahaan berupaya untuk meningkatkan laba dan arus kas yang diperoleh dimasa depan, sehingga peningkatan performa atau kinerja perusahaan sangat penting. Evaluasi kinerja perusahaan biasanya digambarkan dalam laporan keuangan perusahaan.

Indikator kinerja akan dicerminkan oleh rasio-rasio, bagi perusahaan publik indikator rasio-rasio ini akan menjadi salah satu titik fokus dalam pengambilan keputusan, terutama dalam menilai harga saham. Dalam penelitian ini digunakan rasio profitabilitas karena secara umum investor yang menanamkan dananya di pasar modal adalah untuk mencari keuntungan semaksimal mungkin. Keuntungan yang diperoleh investor atas dananya yang diinvestasikan pada saham berupa laba (dividen) dan selisih harga jual saham dengan harga belinya (capital gain).

Menurut Kamaludin dan Rini (2012) rasio profitabilitas digunakan untuk menunjukkan gambaran tentang tingkat efektivitas pengelolaan perusahaan dalam menghasilkan laba. Ukuran yang biasa digunakan adalah Return On Asset (ROA), Return On Equity (ROE), Net Profit Margin (NPM) dan Earning Per Share (EPS). Tetapi penggunaan rasio keuangan sebagai alat pengukuran akuntansi konvensional memiliki kelemahan utama yaitu mengabaikan adanya biaya modal, sehingga sulit mengetahui apakah suatu perusahaan telah berhasil menciptakan nilai atau tidak. Maka dikembangkan konsep baru yaitu Economic Value Added (EVA). EVA merupakan pendekatan baru dalam menilai kinerja perusahaan dengan memperhatikan secara adil ekspektasi penyandang dana dan memberikan tolak ukur seberapa jauh perusahaan telah memberikan nilai tambah kepada pemegang saham dalam suatu periode tertentu (Kamaludin dan Rini 2012).

Salah satu industri yang menarik diamati kinerja keuangannya adalah industri semen. Industri semen diyakini akan mengalami pertumbuhan positif dengan semakin berkembangnya proyek-proyek pembangunan infrastruktur di Indonesia dalam skala besar dan dalam waktu yang bersamaan. Hal ini berdampak langsung pada permintaan semen dalam negeri. Melihat perkembangan data yang ada, sampai dengan kuartal III tahun 2012 penjualan semen di dalam negeri masih terus menunjukkan peningkatan apabila dibandingkan dengan tahun-tahun sebelumnya, hal tersebut dapat dilihat pada Gambar 1. 


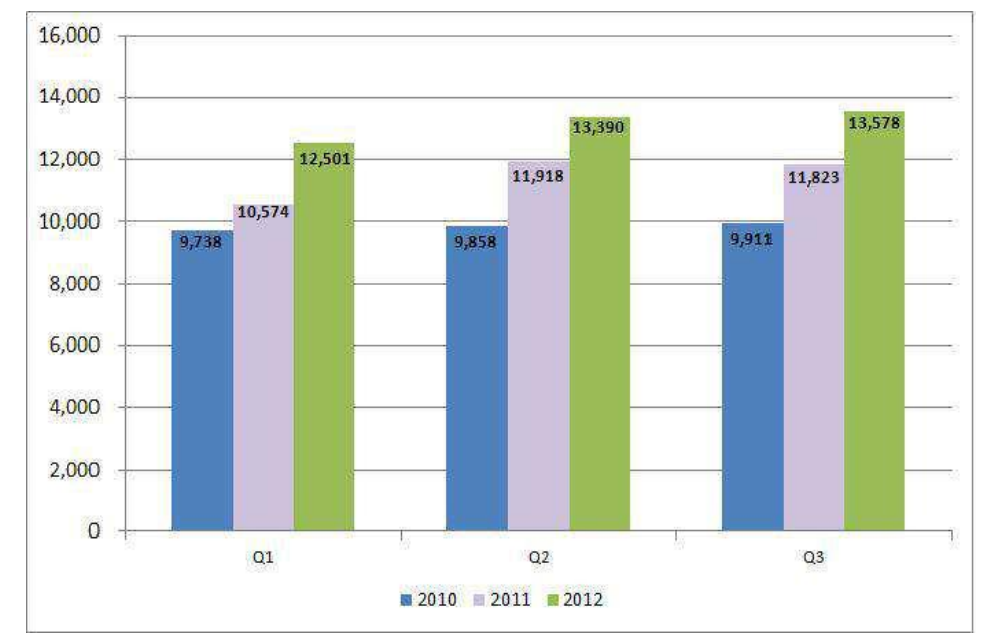

Gambar 1. Penjualan semen pada tahun 2010-2012 triwulan I, II dan III Sumber: ASI (2013)

Angka penjualan semen selama tahun 2012 yang digambarkan pertiga bulan (Gambar 1) mengalami peningkatan yang cukup tinggi. Persentase peningkatan dari masing-masing triwulan dibandingkan dengan periode 2011 adalah sebagai berikut: triwulan I meningkat sebesar 18\%, triwulan II 12\% dan triwulan III 15\%. Tingginya angka penjualan semen tersebut tidak lepas dari adanya proyek Masterplan Percepatan dan Perluasan Pembangunan Ekonomi Indonesia (MP3EI) yang dicanangkan pemerintah, sehingga semakin banyaknya proyek-proyek besar yang dilakukan secara bersamaan seperti proyek pembangunan beberapa ruas jalan tol dan pembangunan perumahan. Untuk mendukung pertumbuhan industri semen diperlukan dukungan pendanaan, dan salah satu sumber pendanaan yang bisa diperoleh adalah dengan go public.

Penelitian ini bertujuan untuk :

1. Menganalisis kondisi rasio profitabilitas (ROA, ROE, NPM, EPS) dan EVA pada sub sektor industri semen di Bursa Efek Indonesia.

2. Menganalisis pengaruh rasio profitabilitas (ROA, ROE, NPM, EPS) dan EVA terhadap harga saham pada sub sektor industri semen di Bursa Efek Indonesia.

\section{Metode Penelitian}

Penelitian ini dilaksanakan pada bulan Januari 2013 sampai dengan bulan Maret 2013 dan lokasi penelitian pada Bursa Efek Indonesia (data Sekunder). Oleh karena keterbatasan data yang tersedia, jenis data sekunder yang digunakan dalam penelitian ini merupakan laporan keuangan kuartal periode 2009-2011 dari perusahaan semen yang terdaftar di Bursa Efek Indonesia, seperti PT Semen Gresik Tbk, PT Indocement Tunggal Prakarsa Tbk dan PT Holcim Indonesia Tbk. Data lain adalah harga saham pada penutupan setiap akhir kuartal selama 3 periode, jurnal dan sumber lain yang berhubungan dengan penelitian ini. Data sekunder tersebut diperoleh melalui internet website BEI dan website perusahaan semen.

Data dan informasi yang telah dikumpulkan kemudian diolah baik secara manual maupun menggunakan bantuan software computer Eviews 6 untuk dianalisis 
kuantitatif, kemudian diinterprestasikan secara deskriptif. Adapun analisis kinerja keuangan pada sub sektor industri semen dilakukan dengan menggunakan rasio keuangan dan Economic Value Added (EVA), serta analisis regresi data panel untuk mengetahui pengaruh ROA, ROE, NPM, EPS dan EVA terhadap harga saham perusahaan. Sebelum dianalisis menggunakan regresi data panel, perlu digunakan regresi berganda untuk mengolah data tersebut, tapi hasil yang diperoleh terjadi multikolinearitas dan dalam regresi berganda tidak boleh terjadi multikolienaritas. Salah satu cara untuk menghilangkan multikolienaritas adalah dengan menggabungkan data time series dan cross section yaitu data panel.

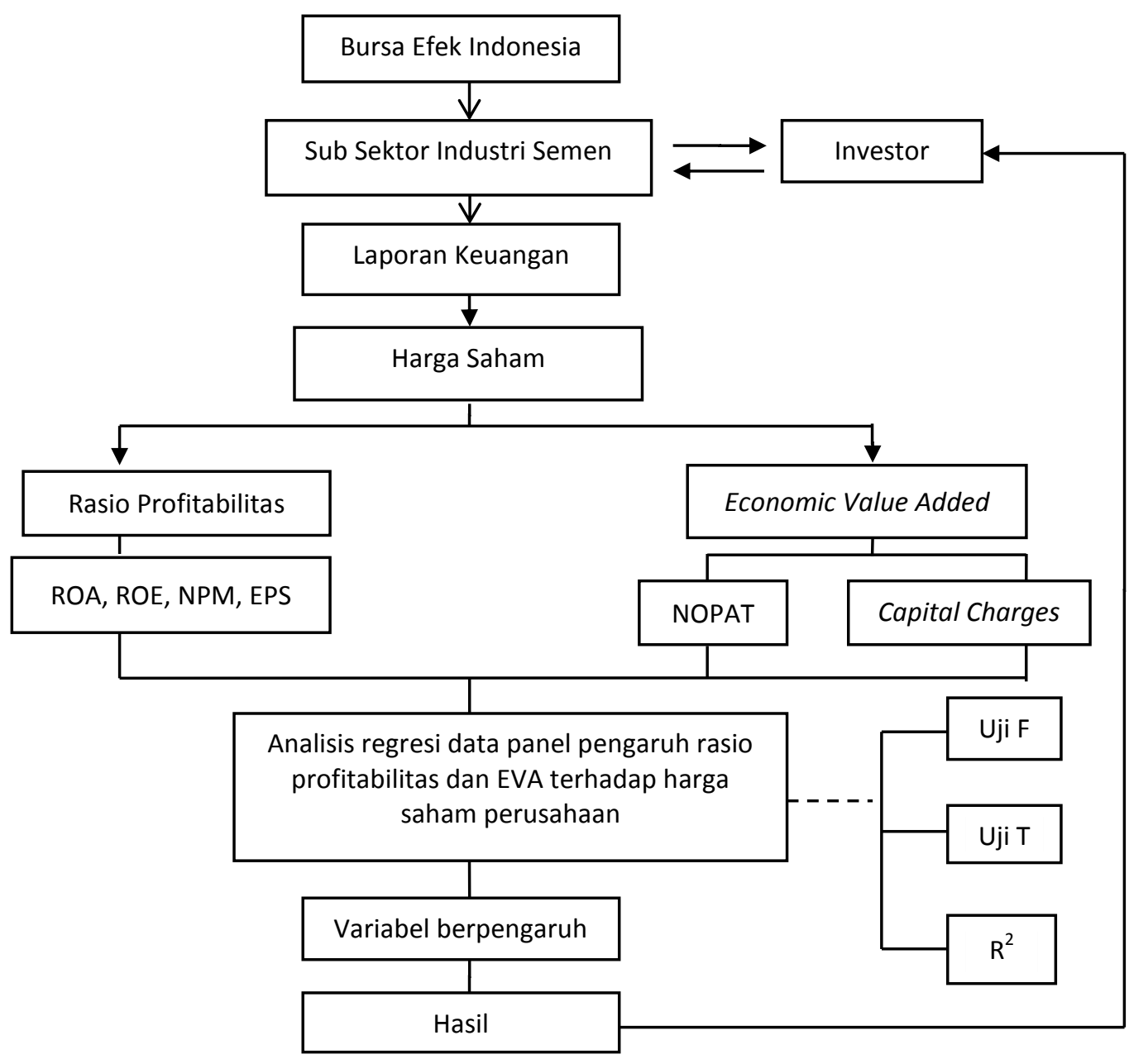

Gambar 2. Kerangka pemikiran

Rasio keuangan yang digunakan dalam penelitian ini adalah rasio profitabilitas dan alat ukur yang digunakan ROA, ROE, NPM dan EPS. Rasio profitabilitas menunjukan seberapa besar tingkat keberhasilan perusahaan di dalam menghasilkan keuntungan. Semakin besar profitabilitas, semakin baik kinerja keuangan perusahaan. Rasio ini juga digunakan sebagai ukuran apakah pemilik atau pemegang saham dapat memperoleh tingkat pengembalian yang pantas atas investasinya. Profitabilitas diukur dengan menggunakan : 
1. ROA digunakan untuk mengukur keuntungan bersih yang diperoleh dari penggunaan aktiva.

$$
\mathrm{ROA}=\frac{\text { Laba Bersih }}{\text { Total Asset }} \times 100 \% \ldots \ldots \ldots \ldots \ldots
$$

2. ROE diukur dengan perbandingan antara laba bersih dengan total modal.

$$
\text { ROE }=\frac{\text { Laba Bersih }}{\text { Modal }} \times 100 \% \ldots \ldots \ldots \ldots \ldots \ldots \text { (2) }
$$

3. NPM merupakan perbandingan antara laba bersih dengan penjualan. Semakin besar NPM, maka kinerja perusahaan akan semakin produktif, sehingga akan meningkatkan kepercayaan investor untuk menanamkan modalnya pada perusahaan tersebut.

$$
\text { NPM }=\frac{\text { Laba Bersih Setelah Pajak }}{\text { Penjualan }} \times 100 \% \ldots \ldots \ldots
$$

4. EPS

Bentuk pemberian keuntungan yang diberikan kepada pemegang saham dari setiap lembar saham yang dimilki.

$$
\text { EPS }=\frac{\text { Laba Bersih }}{\text { Jumlah Saham Beredar }}
$$

EVA merupakan alat analisis untuk mengukur kinerja keuangan perusahaan dengan menghitung laba operasi setelah pajak dikurangi dengan total biaya modal. Menurut Tunggal (2008) Langkah-langkah untuk menghitung EVA adalah:

a. Menghitung Net Operating Profit After Tax (NOPAT)

NOPAT merupakan laba operasi perusahaan dari suatu current operating yang merupakan laba usaha setelah dikurangi beban pajak. Pajak yang digunakan dalam perhitungan EVA adalah pengorbanan yang dikeluarkan oleh perusahaan dalam penciptaan nilai tersebut.

NOPAT = laba bersih + Biaya Bunga

b. Menghitung Invested Capital (IC)

IC merupakan jumlah seluruh pinjaman perusahaan di luar pinjaman jangka pendek tanpa bunga, seperti hutang dagang, biaya yang masih harus dibayar, hutang pajak, uang muka pelanggan, dan sebagainya. 


$$
\text { IC = Kas + working capital requirement + aktiva tetap . . . (6) }
$$

c. Menghitung Weight Average Cost of Capital (WACC)

WACC merupakan jumlah biaya dari masing-masing komponen modal, misalnya pinjaman jangka pendek dan pinjaman jangka panjang (cost of debt) serta setoran modal saham (cost of equity) yang diberikan bobot sesuai dengan proporsinya dalam struktur modal perusahaan.

$$
\begin{aligned}
& \text { WACC }=\{(\mathrm{D} \times \mathrm{Rd})(1-\mathrm{Tax})+(\mathrm{E} \times \mathrm{Re})\} \ldots \ldots \ldots \ldots \text { (7) } \\
& \text { Keterangan: } \\
& \mathrm{D} \quad=\text { Tingkat modal dari hutang (total hutang/total hutang dan ekuitas) } \\
& \mathrm{Rd}=\text { Biaya hutang (biaya bunga /total hutang) } \\
& \mathrm{Tax}=\text { Pajak } \\
& \mathrm{E} \quad=\text { Tingkat modal dari ekuitas (total ekuitas/total hutang dan ekuitas) } \\
& \operatorname{Re}=\text { Biaya ekuitas (1/PER) }
\end{aligned}
$$

d. Menghitung Capital Charges (CC)

CC adalah aliran kas yang dibutuhkan sebagai kompensasi para investor atas risiko usaha dari modal yang ditanamkannya.

$\mathrm{CC}=$ Invested Capital $\times$ WACC $\ldots \ldots \ldots \ldots \ldots$ (8)

e. Menghitung EVA

EVA merupakan laba yang tertinggal setelah dikurangi dengan biaya modal (capital charges) yang diinvestasikan untuk menghasilkan laba tersebut.

EVA $=$ NOPAT - Capital Charges . . . . . . . . . . (9)

Konsep EVA dijelaskan dari tiga ukuran yang dapat digunakan dalam menilai kinerja perusahaan yaitu:

1) Jika EVA > 0, menunjukan terjadi proses nilai tambah perusahaan, kinerja keuangan perusahaan baik.

2) Jika $E V A=0$, menunjuakan posisi impas perusahaan.

3) Jika EVA >0, menunjukan tidak terjadi proses nilai tambah perusahaan, yang mengakibatkan laba yang ada tidak bisa memenuhi harapan investor, sehingga kinerja keuangan perusahaan tidak baik.

Penelitian ini menggunakan regresi data panel dengan metode panel least square dengan menggunakan pembobot cross section weight, tujuannya adalah untuk mengurangi heterogenitas antar unit cross section dan menggunakan metode coefisien covarian white periode untuk mengestimasi covarian yang akan menghasilkan general heterogenitas (Gujarati dan Porter 2010). Pengolahan data dilakukan dengan menggunakan software Microsoft Excel dan E-views 6.

Regresi data panel (pooled data) merupakan gabungan antara data cross section dan data time series. Data cross section adalah data yang dikumpulkan dalam satu waktu terhadap banyak individu, sedangkan data time series adalah data yang dikumpulkan dari waktu ke waktu.

Dalam persamaan garis regresi yang bertindak sebagai variabel dependen adalah harga saham, sedangkan variabel independen diwakili oleh Return on Asset (ROA), 
Return on Equity (ROE), Net Profit Margin (NPM), dan Earning Per Share (EPS) dan Economic ValueAdded (EVA). Formula perhitungannya adalah sebagai berikut:

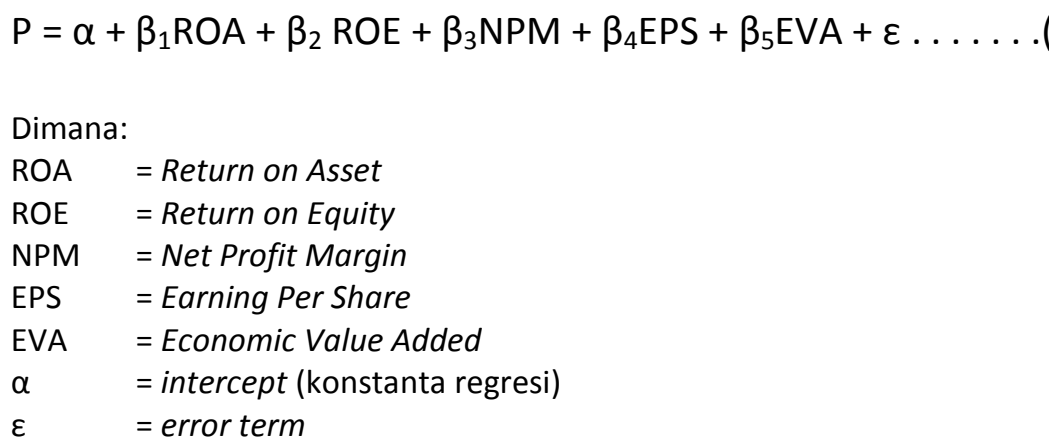

a. Uji Simultan (Uji-F)

Uji simultan ini bertujuan untuk mengetahui pengaruh bersama-sama variabel independen terhadap variabel dependen. Rumusan hipotesis untuk menguji pengaruh variabel bebas terhadap variabel independen secara simultan adalah sebagai berikut:

Ho : Model tidak layak (variabel bebas secara simultan tidak berpengaruh signifikan terhadap variabel tidak bebas)

$\mathrm{Ha}$ : Model layak (variabel bebas secara simultan berpengaruh signifikan terhadap variabel tidak bebas)

Pada penelitian ini terdapat nilai $p$ value yang dibandingkan dengan $\alpha$ sebesar 0.05. Kriteria penerimaan menggunakan nilai Ho, Apabila hasil Ho menunjukkan nilai $>$ $5 \%$ atau 0.05 , maka dapat disimpulkan Ho diterima. Sedangkan apabila hasil Ho menunjukkan nilai $<5 \%$ atau 0.05 , maka dapat disimpulkan Ho ditolak.

\section{b. Uji Parsial (Uji-t)}

Uji t bertujuan untuk menunjukan seberapa besar pengaruh satu variabel individu secara parsial dalam menerangkan variabel dependen.Bentuk pengujiannya adalah melalui Ho dan Ha. Rumusan hipotesis untuk menguji pengaruh variabel bebas terhadap variabel independen secara parsial adalah sebagai berikut :

Ho : Variabel bebas secara parsial tidak berpengaruh signifikan terhadap variabel tidak bebas

$\mathrm{Ha}$ : Variabel bebas secara parsial berpengaruh signifikan terhadap variabel tidak bebas

Pada penelitian ini terdapat nilai $p$ value yang dibandingkan dengan $\alpha=0.05$. Kriteria penerimaan menggunakan nilai Ho apabila hasil Ho menunjukkan nila $>5 \%$ atau 0.05, maka dapat disimpulkan Ho diterima. Sedangkan apabila hasil Ho menunjukkan nilai $<5 \%$ atau 0.05 , maka dapat disimpulkan Ho ditolak.

c. Koefisien Determinasi (R Square)

Nilai $R^{2}$ menunjukkan seberapa besar model mampu menjelaskan variabelitas variabel independen. Dimana $\mathrm{R}^{2}$ adalah koefisien determinasi yang artinya besarnya pengaruh variabel independen $X_{1}, X_{2}, X_{3}, X_{4}$ dan $X_{5}$ secara bersama-sama terhadap variabel dependen $(\mathrm{Y})$. 


\section{Hasil dan Pembahasan}

III.1. Analisis Rasio Profitabilitas

1. Return on Asset (ROA)

ROA merupakan perbandingan antara laba bersih yang berhasil diperoleh perusahaan terhadap total aset yang dimiliki. Rasio ini menggambarkan kemampuan perusahaan dalam menghasilkan keuntungan atas aset yang dikelola dalam kegiatan operasional sehari-hari. Hasil perhitungan ROA pada ketiga perusahaan semen yang terdaftar di BEI dapat dilihat pada Gambar 3.

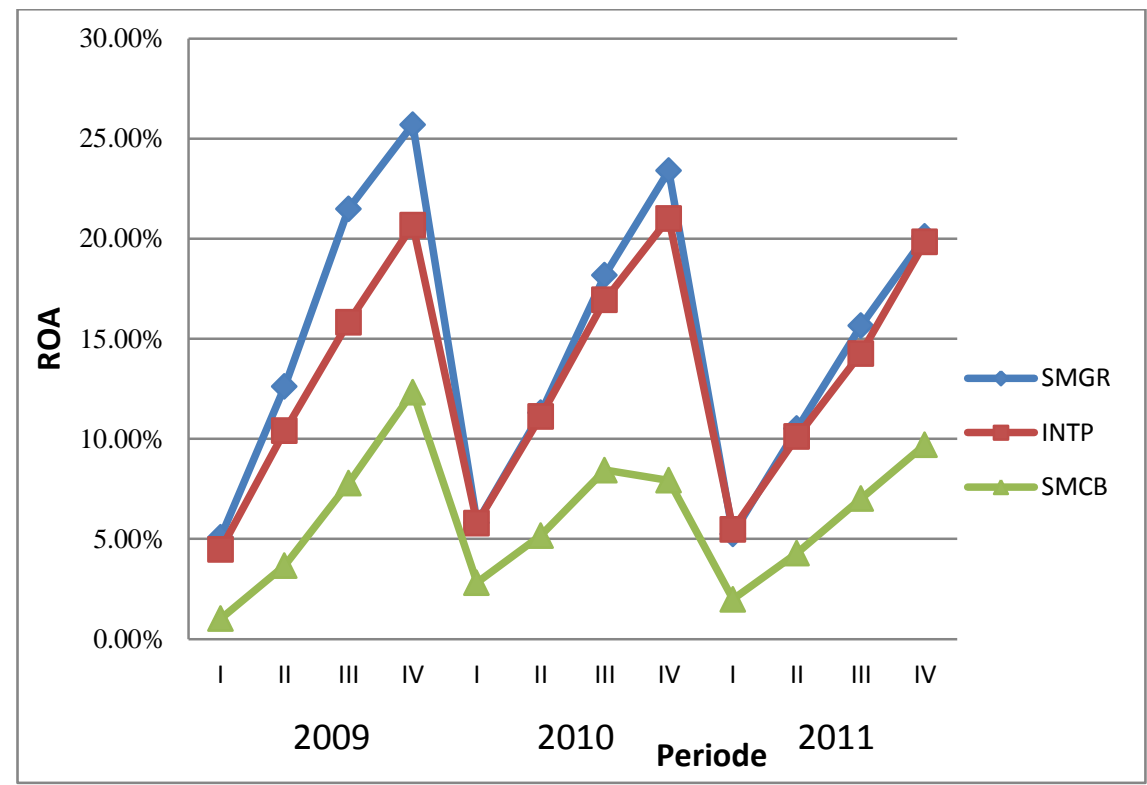

Gambar 3. Grafik ROA sub sektor industri semen yang terdaftar di BEI Sumber: Data BEI diolah

Tingkat ROA yang telah dicapai PT Semen Gresik Tbk dan PT Indocement Tunggal Prakarsa Tbk rata-rata mengalami penurunan setiap periodenya. Pada kuartal III-2010, laba bersih semen gresik naik sebesar $8.09 \%$ dibandingkan periode sama tahun lalu dan aset naik sebesar $0.84 \%$, dan laba bersih naik lebih besar dari pada aset, sehingga memperoleh penurunan nilai ROA pada kuartal III-2010 tersebut. Hal ini terjadi karena laba bersih yang diperoleh meningkat lebih kecil dari pada aset sehingga menyebabkan penurunan pada nilai ROA. Walaupun rata-rata nilai ROA yang dihasilkan oleh PT Semen Gresik Tbk menurun tetapi secara teori nilai ROA yang baik berada lebih dari 2\% (Irham 2012). Dan PT Semen Gresik Tbk memperoleh nilai ROA yang baik karena memperoleh angka ROA lebih dari $2 \%$.

PT Holcim Indonesia Tbk memperoleh angka ROA yang paling rendah dibandingkan dengan kedua pesaingnya, dan pada kuartal 1-2009. PT Holcim Indonesia Tbk memperoleh nilai ROA kurang baik, yaitu sebesar $1.02 \%$ tetapi pada kuartal selanjutnya PT Holcim Indonesia Tbk dapat memperoleh ROA yang baik (3.67\%), artinya PT Holcim Indonesia Tbk sudah mampu menghasilkan keuntungan. 


\section{Return on Equity (ROE)}

ROE merupakan salah satu ukuran rasio keuangan yang berbasiskan laba, dan hasil perhitungan ROE PT Semen Gresik Tbk, PT Indocement Tunggal Prakarsa Tbk dan PT Holcim Indonesia Tbk periode 2009-2011 kuartal I-IV dapat dilihat pada Gambar 4.

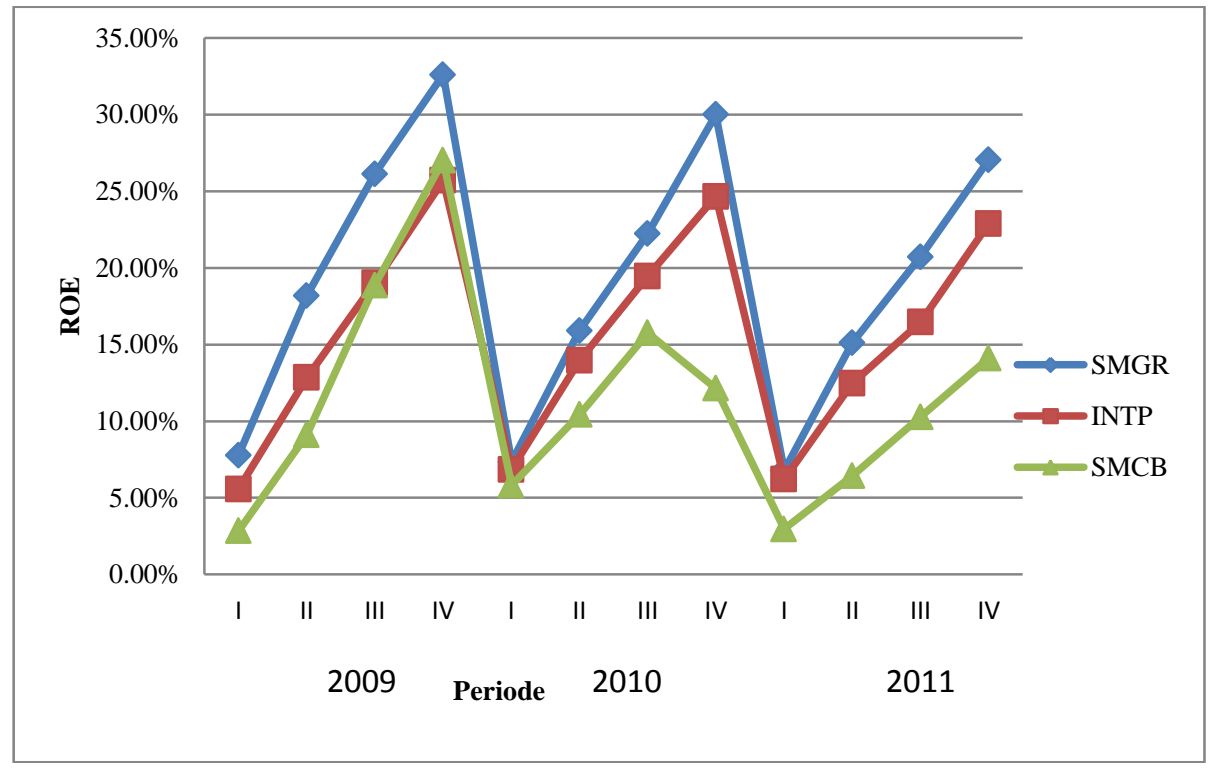

Gambar 4. Grafik ROE sub sektor industri semen yang terdaftar di BEI Sumber: Data BEI diolah

Tingkat ROE pada PT Semen Gresik Tbk pada periode 2010-2011 kuartal I ratarata mengalami penurunan dari kuartal periode sebelumnya. Pada kuartal I-2010 sebesar 7.34\% dan kuartal I-2011 sebesar 6.78\%. Hal ini menunjukkan bahwa laba bersih yang diperoleh meningkat lebih kecil dari ekuitas, walau pada kuartal I-2010 secara persentase laba bersih yang diperoleh meningkat sebesar $0.85 \%$ dan ekuitas meningkat sebesar $0.80 \%$. Tingkat ROE PT Indocement Tunggal Prakarsa Tbk pada periode 2009 mengalami peningkatan dari kuartal I-IV, angka ROE tertinggi sebesar $25.71 \%$ pada kuartal IV. Peningkatan ROE terjadi karena jumlah laba bersih meningkat lebih besar dibandingkan dengan meningkatnya jumlah ekuitas. ROE PT Indocement Tunggal Prakarsa Tbk rata-rata mengalami penurunan dari periode sebelumnya sebesar 6.21\% (kuartal I), 12.47\% (kuartal II), 16.46\% (kuartal III) dan 22.89\% (kuartal IV). Tingkat ROE pada PT Holcim Indonesia Tbk mengalami penurunan setiap periodenya. Pada akhir periode 2009, tingkat ROE sebesar $27.02 \%$, dan pada akhir periode 2010 hanya sebesar 12.14\%, tetapi pada akhir periode 2011 mengalami peningkatan nilai ROE kembali yaitu menjadi sebesar $14.12 \%$. Hal ini menunjukkan perusahaan mengalami perbaikan kinerja dalam pengelolaan atas ekuitas yang dimiliki sehingga laba bersih yang dicapai cenderung mengalami peningkatan kembali. 


\section{Net Profit Margin (NPM)}

Perhitungan NPM perbandingan antara laba bersih dengan penjualan. Hasil perhitungan NPM PT Semen Gresik Tbk, PT Indocement Tunggal Prakarsa Tbk dan PT Holcim Indonesia Tbk periode 2009-2011 kuartal I-IV dapat dilihat pada Gambar 5.

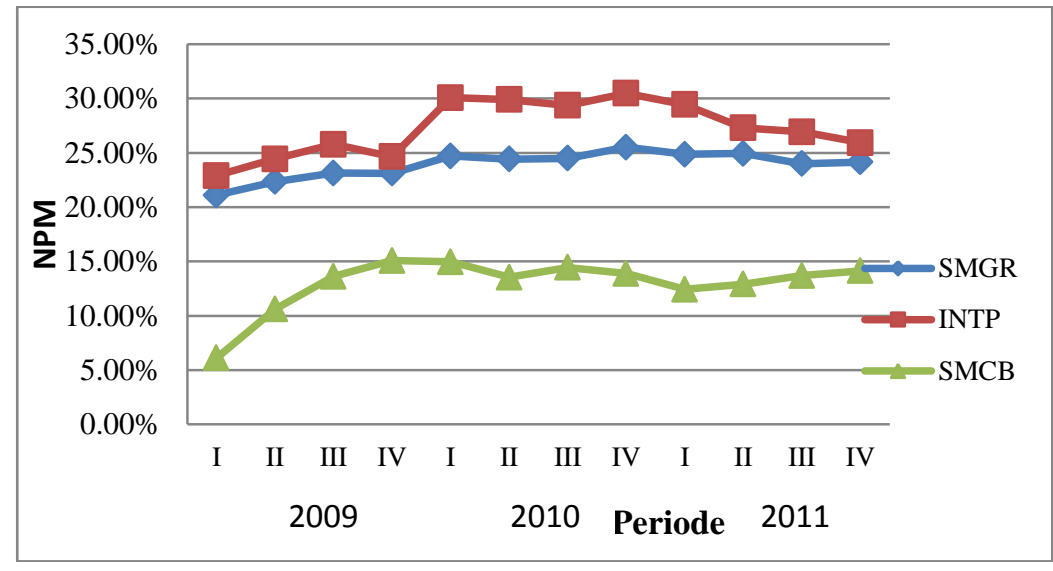

Gambar 5. Grafik NPM sub sektor industri semen yang terdaftar di BEI Sumber: Data BEI diolah

Tingkat NPM pada periode 2009-2010 PT Semen Gresik Tbk selalu mengalami peningkatan. Pada akhir kuartal tahun 2009 angka NPM sebesar 23.12\% dan pada 2010 meningkat menjadi $25.33 \%$. Hal ini terjadi karena laba bersih yang dihasilkan cenderung meningkat, dimana pada kuartal IV-2010 meningkat 0.90\% dan penjualan meningkat sebesar $1.00 \%$. Pada periode 2009-2010 NPM yang dihasilkan PT Indocement Tunggal Prakarsa Tbk mengalami peningkatan, hal ini terjadi karena laba bersih meningkat lebih kecil dibandingakan dengan penjualan. Angka NPM tertinggi terjadi pada periode 2010 (kuartal IV) yaitu sebesar 30.49\%. Semakin besar NPM, maka kinerja perusahaan akan semakin produktif sehingga akan meningkatkan kepercayaan investor untuk menanamkan modalnya pada perusahaan.

Tingkat NPM yang dihasilkan PT Holcim Indonesia Tbk pada 2009 mengalami peningkatan dari kuartal I-IV, sedangkan pada kuartal IV periode 2010 mengalami penurunan dari $15.07 \%$ menjadi $13.89 \%$. Hal ini menunjukkan bahwa kinerja perusahaan kurang produktif. Tetapi pada kuartal IV periode 2011 nilai NPM PT Holcim Indonesia Tbk mengalami peningkatan sebesar $14.13 \%$ dari kuartal periode sebelumnya, hal ini terjadi karena laba bersih meningkat lebih besar dibandingakan dengan penjualan.

\section{Earning Per Share (EPS)}

EPS digunakan untuk mengukur seberapa besar tiap lembar saham dapat menghasilkan keuntungan untuk pemiliknya dan dapat juga digunakan untuk mengukur keberhasilan manajemen dalam mencapai keuntungan bagi para pemilik perusahaan. Data EPS PT Semen Gresik Tbk, PT Indocement Tunggal Prakarsa Tbk dan PT Holcim Indonesia Tbk periode 2009-2011 ditunjukkan pada Gambar 6. 


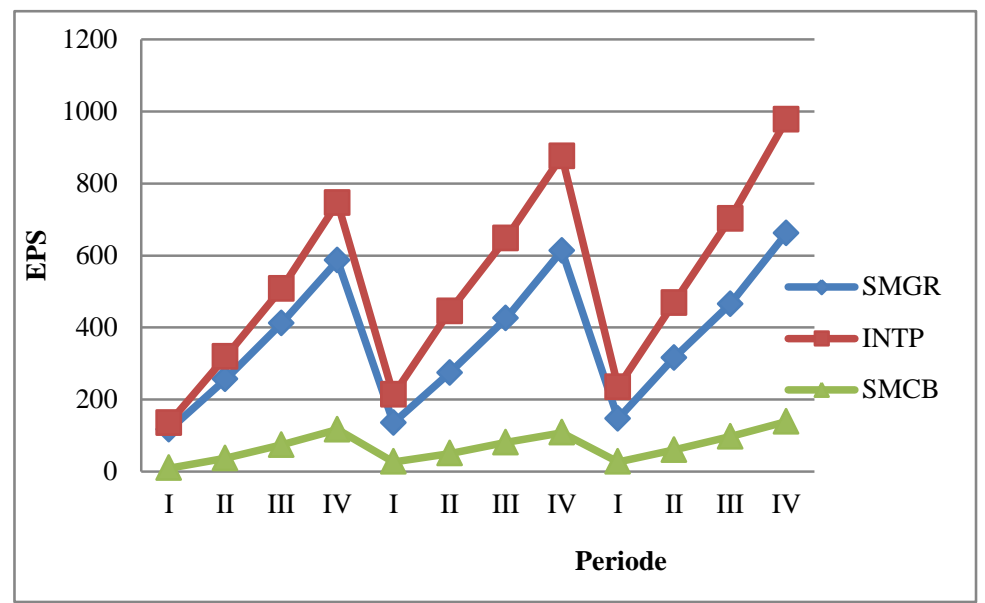

Gambar 6. Grafik EPS sub sektor industri semen yang terdaftar di BEI Sumber: Data BEI diolah

Hasil yang ditunjukkan pada Gambar 6 menggambarkan bahwa tingkat EPS pada PT Semen Gresik Tbk mengalami peningkatan setiap akhir periodenya. Pada kuartal IV2009 tingkat EPS sebesar 586, pada kuartal IV-2010 sebesar 613. Hal ini karena laba bersih yang dicapai perusahaan tinggi, sehingga akan menghasilkan laba yang besar pula bagi investornya.

Tingkat EPS PT Indocement Tunggal Prakarsa Tbk mengalami peningkatan setiap akhir periodenya. Pada kuartal IV-2009 sebesar 746.12, periode kuartal IV-2010 EPS menjadi 876.05 dan kuartal IV-2010 yang merupakan angka EPS tertinggi dari PT Indocement yaitu sebesar 977.10. Pada periode 2010 kuartal IV terjadi penurunan angka EPS pada PT Holcim Indonesia Tbk, hal ini terjadi karena laba bersih yang diperoleh menurun sebesar $1.07 \%$ sehingga angka EPS juga ikut menurun. Sedangkan pada periode 2011 mengalami peningkatan setiap kuartalnya yaitu sebesar 27 (kuartal I), 60 (kuartal II), 97 (kuartal III) dan 139 (kuartal IV). Hal ini menunjukkan bahwa PT Holcim Indonesia Tbk mampu meningkatkan laba bersih pada periode 2011. Dengan meningkatnya laba bersih dan EPS tersebut, maka dapat memberikan kepercayaan kepada investor untuk menanamkan modalnya. Karena, semakin tinggi angka EPS maka semakin tinggi pula laba yang akan diberikan kepada investor.

\section{III.2. Kondisi Economic Value Added (EVA)}

Perhitungan EVA adalah NOPAT - Capital Charges. Apabila EVA >0 (positif), Jika EVA lebih dari 0 , menunjukan terjadi proses nilai tambah perusahaan dan kinerja keuangan perusahaan baik. Apabila nilai EVA kurang dari 0 menunjukan bahwa tidak terjadi proses nilai tambah perusahaan, yang mengakibatkan laba yang ada tidak bisa memenuhi harapan investor, sehingga kinerja keuangan perusahaan tidak baik. Nilai EVA yang berhasil dicapai oleh PT Semen Gresik Tbk, PT Indocement Tunggal Prakarsa Tbk dan PT Holcim Indonesia Tbk periode 2009-2011 ditunjukkan pada Gambar 7. 


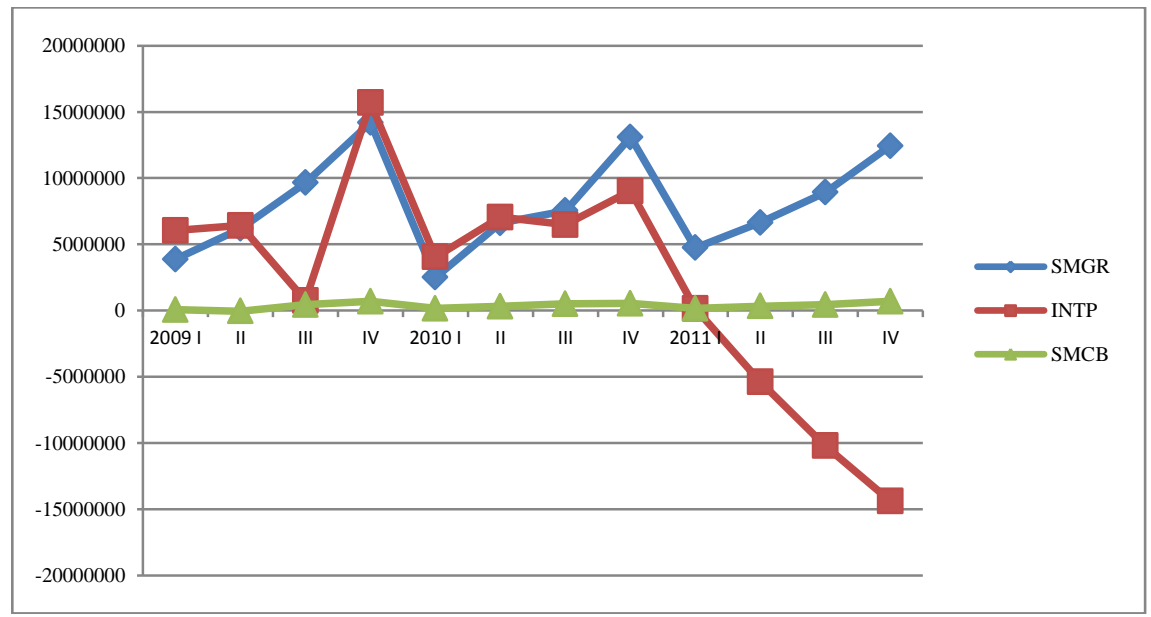

Gambar 7. Grafik EVA sub sektor industri semen yang terdaftar di BEI Sumber: Data BEI diolah

Hasil perhitungan EVA PT Semen Gresik Tbk pada periode 2009-2011, menunjukkan nilai EVA yang positif, hal tersebut menunjukan perusahaan mengalami kenaikkan kinerja dibanding periode sebelumnya. Nilai EVA yang positif menunjukkan bahwa tingkat pengembalian yang dihasilkan oleh perusahaan melebihi biaya modal atau tingkat pengembalian yang diharapkan oleh investor atas investasi yang dilakukannya.

Pada kuartal III-2011 PT Indocement Tunggal Prakarsa Tbk memiliki angka EVA yang negatif pada kuartal II, III dan IV pada periode 2011 hal tersebut terjadi karena biaya yang harus dikeluarkan untuk pembiayaan modal yang terukur dengan capital charges lebih besar dibandingkan NOPAT yang diperoleh perusahaan. Hal tersebut menandakan bahwa perusahaan belum berhasil menciptakan nilai tambah kekayaan atas modal yang diinvestasikan investor. PT Holcim Indonesia Tbk pada periode 2009 kuartal II memiliki nilai EVA yang negative sebesar -54.623, hal ini menandakan bahwa perusahaan belum berhasil menciptakan nilai tambah kekayaan atas modal yang diinvestasikan investor. Hal ini dikarenakan NOPAT yang berhasil dicapai pada kuartal tersebut lebih rendah dibandingkan dengan biaya modal yang dihasilkan oleh PT Holcim Indonesia Tbk. Tetapi pada periode selanjutnya PT Holcim Indonesia Tbk memperoleh nilai EVA yang positif. Laba yang dihasilkan perusahaan sudah dapat melebihi harapan investor dan perusahaan dapat mengembalikan pinjaman kreditur.

\section{III.3. Analisis Pengaruh ROA, ROE, NPM, EPS dan EVA terhadap Harga Saham}

1. Analisis Regresi Data Panel

Analisis regresi data panel adalah untuk melihat ada tidaknya pengaruh signifikansi variabel independen, yaitu ROA, ROE, NPM, EPS dan EVA terhadap variabel dependen yaitu harga saham. Hasil analisis regresi data panel ditunjukkan pada Tabel 1. 
Tabel 1. Hasil analisis regresi data panel

\begin{tabular}{ccccc}
\hline Variabel & Coefficient & Std. Error & t-Statistic & Prob. \\
\hline ROA & -463.4394 & 106.2815 & -4.360491 & 0.0002 \\
ROE & 45.43118 & 12.69964 & 3.577360 & 0.0013 \\
NPM & 409.9700 & 107.9373 & 3.798225 & 0.0008 \\
EPS & 17.11939 & 2.326743 & 7.357664 & 0.0000 \\
EVA & 0.000164 & $8.66 E-05$ & 1.898801 & 0.0683 \\
C & -2280.029 & 1997.414 & -1.141490 & 0.2637 \\
\hline
\end{tabular}

Berdasarkan hasil analisa regresi dari data panel pada Tabel 1 dapat disusun persamaan regresi sebagai berikut:

$$
\begin{aligned}
P= & -2280.029-463.4394 \mathrm{ROA}+45.43118 \mathrm{ROE}+409.9700 \mathrm{NPM}+17.11939 \mathrm{EPS}+ \\
& 0.000164 \mathrm{EVA}+\text { eit } \ldots \ldots \ldots \ldots \ldots \ldots \ldots \ldots \ldots \ldots \text { (11) }
\end{aligned}
$$

\section{Uji F (simultan)}

Uji $\mathrm{F}$ menunjukkan apakah variabel bebas yang dimasukkan dalam model mempunyai pengaruh secara bersama-sama (simultan) terhadap variabel terikatnya.

Tabel 2. Hasil analisis Uji F (simultan)

\begin{tabular}{lcll}
\hline \multicolumn{4}{c}{ Weighted Statistics } \\
\hline R-squared & 0.955115 & Mean dependent var & 8192.932 \\
Adjusted R-squared & 0.943478 & S.D. dependent var & 4096.046 \\
S.E. of regression & 1510.822 & Sum squared resid & 61629755 \\
F-statistic & 82.07605 & Durbin-Watson stat & 1.612866 \\
Prob(F-statistic) & 0.000000 & & \\
\hline
\end{tabular}

Hasil analisis seperti tercantum pada Tabel 2 dapat disimpulkan bahwa secara simultan variabel ROA, ROE, NPM, EPS dan EVA berpengaruh secara signifikan terhadap harga saham, karena nilai p-value $(0.000)<$ alpha $(0.05)$. Hal ini berarti tolak $\mathrm{Ho}$, sehingga variabel bebas secara bersama berpengaruh secara signifikan terhadap variabel tidak bebas (Harga Saham).

\section{Ujit}

Uji $\mathrm{t}$ digunakan untuk menguji signifikansi regresi masing-masing variabel independen. Jika nilai probabilitas lebih kecil dari tingkat signifikan yang diharapkan ( $\alpha$ $=5 \%)$, maka terdapat pengaruh yang signifikan antara variabel dependen dengan independennya tertentu secara parsial.

Tabel 3. Hasil analisis Uji t

\begin{tabular}{ccccc}
\hline Variabel & Coefficient & Std. Error & t-Statistic & Prob. \\
\hline ROA & -463.4394 & 106.2815 & -4.360491 & 0.0002 \\
ROE & 45.43118 & 12.69964 & 3.577360 & 0.0013 \\
NPM & 409.9700 & 107.9373 & 3.798225 & 0.0008 \\
EPS & 17.11939 & 2.326743 & 7.357664 & 0.0000 \\
EVA & 0.000164 & $8.66 E-05$ & 1.898801 & 0.0683 \\
C & -2280.029 & 1997.414 & -1.141490 & 0.2637 \\
\hline
\end{tabular}


Hasil uji-t menunjukkan bahwa nilai p-value pada ROA, ROE, NPM, EPS berturutturut $(0.0002 ; 0.0013 ; 0.0008 ; 0.0000)<$ alpha $(0.05)$, maka tolak Ho, sehingga ROA, ROE, NPM, EPS secara parsial berpengaruh signifikan terhadap variabel tidak bebas (Harga Saham). Nilai p-value pada EVA (0.0683) > alpha (0.05) maka berarti terima Ho, sehingga EVA secara parsial tidak berpengaruh signifikan terhadap variabel tidak bebas.

\section{4. $U j i R^{2}$ (Koefisien Determinasi)}

Uji $R^{2}$ menunjukkan seberapa besar model mampu menjelaskan variabilitas variabel independen. $\mathrm{R}^{2}$ adalah koefisien determinasi yang mengukut besarnya pengaruh variabel independen secara bersama-sama terhadap variabel dependen.

Tabel 4. Hasil analisis Uji $\mathrm{R}^{2}$

\begin{tabular}{lccc}
\hline \multicolumn{3}{c}{ Weighted Statistics } \\
\hline R-squared & 0.955115 & Mean dependent var & 8192.932 \\
Adjusted R-squared & 0.943478 & S.D. dependent var & 4096.046 \\
S.E. of regression & 1510.822 & Sum squared resid & 61629755 \\
F-statistic & 82.07605 & Durbin-Watson stat & 1.612866 \\
Prob(F-statistic) & 0.000000 & & \\
\hline
\end{tabular}

Estimasi memberikan hasil $\mathrm{R}^{2}$ sebesar 0.95 yang menunjukkan bahwa terjadi hubungan antara variabel independen dengan variabel dependen. Variabel independen yang ada pada regresi ini mampu menjelaskan sebesar $95.51 \%$ pola pergerakan harga saham pada sektor industri semen, sedangkan $4.49 \%$ kemungkinan terkait faktor lain yang tidak dijelaskan ke dalam model ini.

\section{III.4. Implikasi Manajerial}

Rasio keuangan merupakan acuan bagi para investor, karena rasio ini memberikan gambaran kondisi keuangan suatu perusahaan. Sehingga para investor tidak salah dalam melakukan investasi dalam suatu perusahaan yang akan meningkatkan keuntungan bagi investor.

1. Hasil penelitian ini menunjukkan bahwa rasio profitabilitas memberikan pengaruh yang signifikan terhadap haga saham sehingga rasio ini baik digunakan oleh investor untuk memprediksi harga saham. Investor sebaiknya selalu memperhatikan dan menggunakan informasi tentang kinerja perusahaan dari sisi rasio profitabilitas, karena informasi tersebut mempunyai pengaruh terhadap harga saham perusahaan. Hal ini dimaksudkan agar investor dapat mengambil keputusan yang tepat dalam memilih suatu peusahaan untuk berinvestasi.

2. Hasil penelitian menyatakan bahwa EVA tidak berpengaruh signifikan secara parsial terhadap harga saham dengan nilai signifikasi 0.0683 . Hal tersebut berarti tidak memberikan gambaran bagi investor mengenai harga saham yang diperoleh dalam suatu periode. Tetapi secara simultan EVA memiliki pengaruh signifikan terhadap harga saham sebesar 0.0000, sehingga EVA memberikan tolak ukur seberapa jauh perushaaan telah memberikan nilai tambah kepada pemegang saham dalam periode tertentu. Sehingga, jika para manajer memfokuskan pada EVA, maka para 
manajer akan konsisten dalam mengelola perusahaan untuk memaksimalkan kekayaan pemegang saham.

3. Bagi perusahaan dalam mengendalikan kinerja perusahaan juga harus memperhatikan tentang rasio rasio profitabilitas, sehingga perusahaan tersebut senantiasa diperhatikan oleh para investor. Perusahaan yang mempunyai kinerja keuangan baik akan berdampak pada harga sahamnya akan semakin baik, dengan demikian jika harga saham perusahaan naik maka keuntungan akan dapat dinikmati oleh perusahaan maupun oleh investor.

\section{Kesimpulan}

Kondisi rasio profitabilitas (ROA, ROE, NPM, EPS) pada sub sektor industri semen memperoleh nilai rasio profitabilitas yang berfluktuasi. Pada dasarnya dari ketiga perusahaan semen tersebut memperoleh nilai rasio diatas rata-rata. Kondisi Economic Value Added pada sub sektor industri semen rata-rata memperoleh kinerja yang positif artinya perusahaan mampu memberikan nilai tambah kepada investor.

Secara simultan variabel ROA, ROE, NPM, EPS dan EVA berpengaruh secara signifikan terhadap harga saham, karena nilai $p$-value $(0.000)<$ alpha $(0.05)$ maka tolak Ho sehingga variabel bebas berpengaruh secara signifikan terhadap variabel tidak bebas (Harga Saham). Secara parsial, rasio profitabilitas yang terdiri dari ROA, ROE, EPS, dan NPM berpengaruh signifikan terhadap harga saham. Hasil ini ditunjukkan melalui uji T nilai p-value pada ROA, ROE, NPM, EPS berturut-turut $(0.0002 ; 0.0013$; $0.0008 ; 0.0000)<$ alpha $(0.05)$, maka Tolak Ho. Nilai p-value pada EVA $(0.0683)>$ alpha (0.05) maka terima Ho sehingga EVA secara parsial tidak berpengaruh signifikan terhadap harga saham.

\section{Daftar Pustaka}

[ASI] Asosiasi Semen Indonesia. 2013. Penjualan semen pada tahun 2010-2012 triwulan I, II dan III [Internet]. Tersedia pada: www.asi.or.id, 2013

Irham F. 2012. Pengantar Pasar Modal. Bandung [ID]: Alpabeta.

Gujarati DN, Porter DC. 2010. Dasar-Dasar Ekonometrika. Jakarta [ID]: Salemba Empat. Kamaludin, Indriani R. 2012. Manajemen Keuangan "Konsep Dasar dan Penerapannya". Edisi Revisi. Bandung [ID]: Mandar Maju.

Keown AJ. 2004. Manajemen Keuangan: Prinsip-prinsip dan Aplikasi. Edisi 9. Jakarta [ID]: PT Indeks Kelompok Gramedia.

Tunggal AW. 2008. Economic Value Added (EVA) Teori, Soal dan Kasus. Jakarta [ID]: Haravindo.

www.idx.co.id, 2013

www.holcim.co.id, 2013

www.indocement.co.id, 2013

www.semengresik.com, 2013 